\title{
ЭФФЕКТИВНОСТЬ ПРИМЕНЕНИЯ МИКРОБИОЛОГИЧЕСКИХ ПРЕПАРАТОВ НА ПОСЕВАХ СОИ В КБР
}

Хакулов И.В.

Батырова A.M.

Бекалдиева Н.М.

Забаков А.Б.

Бейтуганов И.Р.

Научный руководитель: Ханиева И.М.

д.с-Х.Н, профессор

ФГБОУ ВО Кабардино-Балкарский ГАУ

\begin{abstract}
Аннотация: В статье отражены данные, полученные в ходе полевого эксперимента, установлено, что внедрение сои в производственные посевы с использованием 125 д.в. боризированного суперфосфата по зябливую вспашку. Затем проводя предпосевную обработку семян сульфатом цинка (10 г на гектарную норму семян), сернокислым марганцем (20 г на гектарную норму семян), 50\% молибдатом аммония (50 г на гектарную норму семян) в комплексе Хайстик (Bradyrhizobium japonicum) - 400 г на гектарную норму семян позволит производственникам в условиях Кабардино-Балкарии получать стабильно прибавку урожая семян в 1,1 т/га или более $60 \%$.

Ключевые слова: микроэлементы, соя, сорт Вилана, микробиологические препараты, инокуляция семян, урожай, качество, структура урожая.
\end{abstract}

\section{EFFICIENCY OF APPLICATION OF MICROBIOLOGICAL PREPARATIONS ON SOYBEAN CROPS IN CBD}

\footnotetext{
Abstract: The article reflects the data obtained during the field experiment, it was established that the introduction of soybeans into production crops using 125 a.c. borated superphosphate for fall plowing and then pre-sowing treatment of seeds with zinc sulfate ( $10 \mathrm{~g}$ per hectare seed rate), manganese sulfate ( $20 \mathrm{~g}$ per hectare seed rate), $50 \%$ ammonium molybdate (50 g per hectare seed rate) in the complex Haystic (Bradyrhizobium japonicum) - $400 \mathrm{~g}$ per hectare of seeds to allow 
producers to receive in the conditions of Kabardino-Balkaria a stable increase in seed yield of $1.1 \mathrm{t} /$ ha or more than $60 \%$.

Key words: microelements, soybeans, Vilana variety, microbiological preparations, seed inoculation, yield, quality, yield structure.

В нынешних условиях увеличение производства сельскохозяйственных культур можно только достичь путем высоких агротехнологий. Необходимо внедрять экологически безопасные приемы внесения удобрений и пестицидов, a также минимализировать применения средств химизации с помощью использования прогрессивных технологий.

В настоящее время заграницей в ряде стран применяется технология выращивания растениеводческой продукции путем экологизированных технологий, т.е. экологичное сельскохозяйственное производство (органическое земледелие, альтернативное производство). Путем привлечения максимального использования внешних и внутренних ресурсов, при этом стараясь как можно меньше отрицательно оказывать воздействие на природу, полным отказом от промышленного минерального удобрения или средств химзащиты растений [4].

Нами в 2018-2020 гг. были заложены полевые опыты в условиях учебнопроизводственного комплекса ФГБОУ ВО Кабардино-Балкарского государственного аграрного университета.

Характеристика почвы опытного участка выщелоченный чернозем: по механическому составу тяжелосуглинистая (48,2\% глины), гумуса в пахотном горизонте - 3,8\%, содержание легкогидрозуемого азота - 150 мг/кг, содержание подвижного фосфора среднее -30 мг/га почвы (по Чирикову), обеспеченность обменного калием высокая - 80 мг/кг (по Чирикову), pH-6,5 [2].

Целью наших исследований было следующее, установить как формируются симбиотический аппарат, элементы структуры урожая семян сои в зависимости от комплексного применения микробиологических удобрений и микроэлементов.

Схема полевого опыта:

1) Контроль;

2) Фон + Азотофикс;

3) Фон + Альбит;

4) Фон + Ризобакт;

5) Фон + Хайстик. 
Фоном служили микроэлементы (MoZnMn). Доза препаратов при обработке семян: Азотофикс (Bradyrhizobium japonicum 1097) - 400 г на гектарную норму семян, .Альбит (поли-бета-гидроксимасляная кислота из почвенных бактерий Bacillus megaterium) - 40 мл/т, Ризобакт - 0,2 л/т; Хайстик (Bradyrhizobium japonicum) - 400 г на гектарную норму семян.

Наш полевой опыт мы закладывали по методу рендомизированных блоков [1]. Площадь учетной делянки 50 м2, повторность 4-х кратная. Для опыта использовался сорт сои Вилана. Агротехника общепринятая для зоны. Под зяблевую вспашку вносили 125 д.в. боризированного суперфосфата. Перед посевом мы обрабатывали семена: сульфатом цинка (10 г на гектарную норму семян), сернокислым марганцем (20 г на гектарную норму семян), 50\% молибдатом аммония (50 г на гектарную норму семян), В оптимальные сроки проводили посев сои с нормой 0,5 млн. шт./га и шириной междурядья 60 см. [5].

В нашем эксперименте мы использовали методы: фенологические наблюдения (методика Госсортосети, 1971г.), определяли густоту всходов и растений перед уборкой, определяли содержание сырого белка $(6,25 \mathrm{xN})$, содержание жира (по Сокслету), устанавливали показатели активности симбиотического аппарата (по методике Г.С. Посыпанова, 1991 г.) [2], полученные урожайные данные были математически проанализированы по методу Б.А. Доспехова, 1971 г., биометрические анализы растительных проб с фазы всходов через 15 дней, приурочивая к фазам вегетации.

Полученные результаты исследований доказывают (табл. 1), что совместная обработка микроэлементами + инокуляция семян микробиологическими препаратами значительно изменяют показатели (табл. 1). 
Таблица 1

Структура урожая сои в зависимости от изучаемых

микробиологических препаратов

\begin{tabular}{|c|c|c|c|c|c|c|c|c|c|c|c|c|}
\hline \multirow{3}{*}{$\begin{array}{c}\text { Варианты } \\
\text { опыта }\end{array}$} & \multicolumn{4}{|c|}{ Высота } & \multicolumn{4}{|c|}{ Число } & \multicolumn{4}{|c|}{ Macca } \\
\hline & \multicolumn{2}{|c|}{ растения, } & \multicolumn{2}{|c|}{$\begin{array}{l}\text { прикрепления } \\
\text { нижнего боба, }\end{array}$} & \multicolumn{2}{|c|}{$\begin{array}{c}\text { бобов } \\
\text { на } 1 \text { раст., }\end{array}$} & \multicolumn{2}{|c|}{$\begin{array}{l}\text { семян в } \\
\text { бобе, }\end{array}$} & \multicolumn{2}{|c|}{$\begin{array}{l}\text { семян с } \\
1 \text { раст., }\end{array}$} & \multicolumn{2}{|c|}{$\begin{array}{c}1000 \\
\text { семян, }\end{array}$} \\
\hline & (см) & $\begin{array}{c}\text { откл } \\
\text { от } \\
\text { конт }\end{array}$ & (cM) & $\begin{array}{c}\text { откЛ } \\
\text { от } \\
\text { конт }\end{array}$ & (шт.) & $\begin{array}{c}\text { откл } \\
\text { от } \\
\text { конт }\end{array}$ & (шт.) & $\begin{array}{c}\text { откЛ } \\
\text { от } \\
\text { конт }\end{array}$ & (г) & $\begin{array}{c}\text { откл } \\
\text { от } \\
\text { конт }\end{array}$ & (г) & $\begin{array}{c}\text { откЛ } \\
\text { от } \\
\text { конт }\end{array}$ \\
\hline Контроль & 97,0 & 0,0 & 17,2 & 0,0 & 14,3 & 0,0 & 1,7 & 0,0 & 3,9 & 0,0 & 162,6 & 0,0 \\
\hline $\begin{array}{c}\text { Фон + } \\
\text { Азотофикс }\end{array}$ & 100,0 & 3,0 & 17,2 & 0,0 & 14,4 & 0,1 & 1,8 & 0,1 & 4,2 & 0,3 & 164,7 & 2,1 \\
\hline $\begin{array}{c}\text { Фон + } \\
\text { Ризобакт }\end{array}$ & 102,0 & 5,0 & 17,2 & 0,0 & 14,4 & 0,1 & 1,9 & 0,2 & 4,6 & 0,7 & 171,7 & 9,1 \\
\hline $\begin{array}{l}\text { Фон + } \\
\text { Альбит }\end{array}$ & 114,1 & 17,1 & 18,2 & 1,0 & 14,1 & $-0,2$ & 2,1 & 0,4 & 5,3 & 1,4 & 177,8 & 15,2 \\
\hline $\begin{array}{c}\text { Фон + } \\
\text { Хайстик }\end{array}$ & 111,1 & 14,1 & 20,2 & 3,0 & 16,6 & 2,3 & 2,3 & 0,6 & 7,2 & 3,3 & 189,9 & 27,3 \\
\hline
\end{tabular}

Как видно из таблицы 1, в наиболее выгодном цвете находится вариант Фон + Хайстик, затем вариант Фон + Альбит. Так, вариант Фон + Хайстик по высоте 14,1 см, высоте прикрепления початка 3,0 см, числу бобов на 1 растений 2,3 шт., семян в бобе 0,6 шт., по массе семян с 1 растения 3,3 г, по массе 1000 семян 27,3 г. Тоже самое можно отметить по варианту Фон +Альбит, где показатели были несколько скромнее. Так, по высоте 17,1 см, высоте прикрепления початка 1,0 см, числу бобов на 1 растений - 0,2 шт., семян в бобе 0,4 шт., по массе семян с 1 растения 1,4 г, по массе 1000 семян 15,2 г.

По другим вариантам показатели особо не отличались от контроля.

Применение в комплексе микроудобрений и микробиологических препаратов дал значительный прирост как самого урожая семян сои, так и хозяйственно-полезных веществ, таких как белок и жир (табл. 2). 
Таблица 2

Влияние микробиологических препаратов на урожайность

и белковую продуктивность семян сои

\begin{tabular}{|c|c|c|c|c|c|c|c|c|c|c|}
\hline \multirow[b]{3}{*}{ Варианты } & \multirow{2}{*}{\multicolumn{2}{|c|}{ Урожайность }} & \multicolumn{4}{|c|}{ Содержание в семенах } & \multicolumn{4}{|c|}{ Сбор 1 га } \\
\hline & & & \multicolumn{2}{|c|}{ белка } & \multicolumn{2}{|c|}{ жира } & \multicolumn{2}{|c|}{ белка } & \multicolumn{2}{|c|}{ жира } \\
\hline & т/га & $\begin{array}{c}\text { ОткЛ } \\
\text { От } \\
\text { конт }\end{array}$ & $\%$ & $\begin{array}{l}\text { откл } \\
\text { от } \\
\text { конт }\end{array}$ & $\%$ & $\begin{array}{c}\text { откл } \\
\text { от } \\
\text { конт }\end{array}$ & кг & $\begin{array}{c}\text { откл } \\
\text { от } \\
\text { конт }\end{array}$ & Кг & $\begin{array}{c}\text { откл } \\
\text { от } \\
\text { конт }\end{array}$ \\
\hline Контроль & 1,73 & 0,0 & 40,3 & 0,0 & 22,5 & 0,0 & 689 & 0 & 385 & 0 \\
\hline $\begin{array}{c}\text { Фон }+ \\
\text { Азотофикс }\end{array}$ & 1,85 & 0,1 & 40,6 & 0,3 & 21,8 & $-0,7$ & 743 & 54 & 399 & 14 \\
\hline $\begin{array}{c}\text { Фон + } \\
\text { Ризобакт }\end{array}$ & 2,12 & 0,4 & 41,7 & 1,4 & 21,2 & $-1,3$ & 876 & 187 & 445 & 60 \\
\hline $\begin{array}{c}\text { Фон + } \\
\text { Альбит }\end{array}$ & 2,44 & 0,7 & 42,0 & 1,7 & 19,9 & $-2,6$ & 1017 & 328 & 482 & 97 \\
\hline $\begin{array}{c}\text { Фон + } \\
\text { Хайстик }\end{array}$ & 2,87 & 1,1 & 43,2 & 2,9 & 18,5 & $-4,0$ & 1227 & 538 & 525 & 140 \\
\hline
\end{tabular}

$\mathrm{HCP}_{0,95} 1,42 \mathrm{r} / \mathrm{ra}$

Ошибка опыта $1,84 \%$

В нашем эксперименте лидирующее положение занимает вариант Фон + Хайстик. На этом варианте отклонение от контроля в урожайности 1,1 т/га, белка $2,9 \%$, жира $-4,0 \%$, сбора белка 538 кг, жира 140 кг (при том что наблюдалось неуклонное снижение жира на каждом варианте).

Исходя из полученных в ходе полевого эксперимента нами сделан следующий вывод, что внедрение сои в производственные посевы с использованием 125 д.в. боризированного суперфосфата по зябливую вспашку. Затем проводя предпосевную обработку семян сульфатом цинка (10 г на гектарную норму семян), сернокислым марганцем (20 г на гектарную норму семян), 50\% молибдатом аммония (50 г на гектарную норму семян) в комплексе Хайстик (Bradyrhizobium japonicum) - 400 г на гектарную норму семян позволит производственникам в условиях Кабардино-Балкарии получать стабильно прибавку урожая семян в 1,1 т/га или более $60 \%$.

\section{Список литературы}

1. Титов И.Н. Отечественные биопрепараты: регуляторы роста и развития растений и гуминовые препараты для современного земледелия // Автореф. на соиск. уч. степ. к. б. н. - ВГПУ. - г. Владимир, 2008, - 34 с. 
2. Ханиева И.М.,, Бозиев А.Л. Эффективность микро- и макроудобрений при выращивании гороха.- Агрохимический вестник. 2005. № 5. c. 022-023.

3. Ханиева И.М. Биоэкологическое обоснование технологических особенностей возделывания гороха в агроландшафтах центральной части Северного Кавказа.-автореферат диссертации на соискание ученой степени доктора сельскохозяйственных наук / Кабардино-Балкарская государственная сельскохозяйственная академия.- Нальчик, 2006

4. Ханиева, И.М. Влияние регуляторов роста на урожайность и фитосанитарное состояние посевов сои в Кабардино-Балкарии / И.М. Ханиева, Б.Х. Жеруков, А.Л. Бозиев, 3.3. Аутлова / Вестник РАСХН, М., №6, 2012г. C. 47-49.

5. Урожайность и качество зерна гороха в зависимости от биопрепаратов и регуляторов роста в условиях предгорной зоны КБР/ Магомедов К.Г., Ханиев М.Х., Ханиева И.М., Бозиев А.Л., Кишев А.Ю. // Фундаментальные исследования.- 2008.- № 5. С. 27-28.

6. Ханиева И.М. Влияние микроэлементов и инокуляции семян на продуктивность посевов гороха / Ханиева И.М., Бозиев А.Л. // Зерновое хозяйство. 2005. № 8. С. 21-22.

7. Ханиева, И.М. Особенности технологии возделывания нута в предгорной зоне КБР / И.М. Ханиева, 3.З.Тарашева // Ж.- «Международные научные исследования», №3.-С.172-175, 